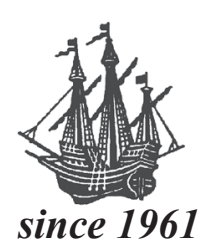

BALTICA Volume 34 Number 2 December 2021: 246-252

https://doi.org/10.5200/baltica.2021.2.8

\title{
Undrained shear strength of glacial till soils and its determining factors
}

\section{Domas Gribulis*, Kastytis Dundulis, Saulius Gadeikis, Sonata Gadeikienè}

Gribulis, D., Dundulis, K., Gadeikis, S., Gadeikienè, S. 2021. Undrained shear strength of glacial till soils and its determining factors. Baltica, 34 (2), 246-252. Vilnius. ISSN 1648-858X.

Manuscript submitted 7 December 2020 / Accepted 15 October 2021/ Available online 20 December 2021

(C) Baltica 2021

\begin{abstract}
This article presents results of the test conducted on the undrained shear strength of till clayey soils of Eastern Lithuania, which are characterized by rigid and very stiff consistency and low plasticity. According to the classification of soils presented in LST EN ISO 14688-2:2018 Geotechnical Investigation and TestingIdentification and Classification of Soil - Part 2: Principles for a Classification, the tested soils are classified as sandy low plasticity clays. The undrained shear strength was tested using the triaxial compression (unconsolidated undrained) method. The test results showed that peculiarities of the particle size distribution had a crucial impact on the undrained strength of these soils, i.e. on the correlation of clay and fine silt fractions with the rest of soil components.
\end{abstract}

Keywords: particle size distribution; tills; optimal soil mixture; soil framework

Domas Gribulis*(domas.gribulis@gf.vu.lt), Kastytis Dundulis (kastytis.dundulis@gmail.com), Saulius Gadeikis (saulius.gadeikis@gf.vu.lt),Sonata Gadeikyte (sonata.gadeikyte@gf.vu.lt),Department of Hydrogeology and Engineering Geology, Faculty of Chemistry and geosciences, Vilnius University, M.K. Čiurlionio str. 21/27, 03101 Vilnius, Lithuania *Corresponding author

\section{INTRODUCTION}

It was already in 1948 that Skempton (1948) proposed the concept of undrained shear strength $\left(\mathrm{c}_{\mathrm{u}}\right)$. In practical geotechnical work, this method has been long applied only for assessing unconsolidated (OCR $<1)$ and water-saturated $\left(\mathrm{S}_{\mathrm{r}}=1\right)$ soils as well as those having low hydraulic conductivity (Ortigão 1995).

In recent decades, the rate of construction has significantly accelerated and values of the load transmitted to the soil base have increased. As a result of accelerated construction processes, dissipation of the pore water pressure in weakly draining and slowly consolidating clay soils has considerably slowed down, and the component of pore water pressure in summed strains has significantly increased. Investigations into structure accidents show that fast load transmission even to consolidated and overconsolidated soils $(\mathrm{OCR} \geq 1)$ results in failure at much lower loads than the failure loads, which are calculated according to effective stress ( $\tan \varphi^{\prime}$ and $\left.\mathrm{c}^{\prime}\right)$ theory. The bearing capacity of the base, compared to the calcu- lated one using the most effective stress, has reduced by up to two times (Powrie 2004).

The introduction of the undrained and unconsolidated condition requirements into practical geotechnical designing of foundations and bases was impelled by the research findings reported by some scientists (Broms, Bennermark 1967; Burland 1990; Sheahan et al. 1996; Powrie 2004). As noted by some authors (Bond, Harris 2008; Frank 2004), the European Union regulations require that in addition to the traditionally used near ground strength parameters $\tan \varphi^{\prime}$ and $\mathrm{c}^{\prime}$, geotechnical design calculations must be made for undrained and unconsolidated conditions according to $c_{u}$ values for all fine-grained soil. As defined in LST EN ISO 14688-2:2018 Geotechnical Investigation and Testing - Identification and Classification of Soil - Part 2: Principles for a Classification, fine soils are those, in which particles smaller than $0.063 \mathrm{~mm}$ exceed $40 \%$. In Russian regulatory documents (Uhov et al. 2004), the criteria for using undrained nonconsolidated shear strength values in designing include the water saturation ratio $\left(S_{r}>0.85\right)$ and the rate of 
consolidation $\left(c_{v} \leq 1 \cdot 10^{7} \mathrm{~cm}^{2} /\right.$ year $)$. In both cases, glacial till clay soils fall within the limits of the soils, for which the assessment must be carried out under undrained unconsolidated conditions. According to Powrie (2004), undrained unconsolidated shear strength values must be used when designing shallow and pile foundations, embankments and retaining walls or when assessing slope stability. Broms, Bennermark (1967) recommend using $c_{u}$ values for assessing the vertical wall height of the dig. As envisaged by Sližyte, Medzvieckas (2013), $c_{u}$ values should be used when assessing foundation sliding.

When assessing the factors, which determine the $c_{u}$ values of clay soils and their change, many researchers point out the overconsolidation ratio $(O C R)$ and plasticity indexes of the physical condition of these soils (Burland 1990; Carrier, Beckman 1984; Sharma, Bora 2003; Sheahan et al. 1996; Wroth 1987). However, in 1996, the tests conducted by Sheahan et al. (1996) rejected the premise that clay soil $O C R$ in the range of 1 to 8 has a more significant impact on the $c_{u}$ value of the undrained unconsolidated strength of these soils. The obtained results showed that there was no direct $c$ impact on $O C R$, while the $c_{u}$ value variation was only $9 \%$.

The test results reported by Carrier, Beckman (1984) as well as those by Sharma, Bora (2003) confirmed that the undrained soil shear strength depends on natural water content $w$ and plasticity index $I_{p}$. A significant logarithmic dependence was determined in the range from the $w_{L}$ liquid limit to the $w_{P}$ plasticity limit. However, the investigation of this logarithmic dependence revealed that as the curve approaches the $w_{P}$ limit and oversteps it, it becomes almost straight, and almost parallel to the value coordination axis.

The data presented by these authors allow stating that $O C R$ as well as $w_{L}, w_{P}$, and $I_{P}$ indexes of our tested glacial till clays were not decisive when assessing changes in undrained soil shear strength values. These indexes vary within minimal ranges, and the search for the key factors should be conducted by investigating the peculiarities of the soil particle size distribution.

\section{RESEARCH METHODS}

A site in northeast Lithuania, where till clay soils $\left(\mathrm{gQ}_{3} \mathrm{~nm}\right)$ of the last glaciation occur, was chosen for sampling. Seven wells were approved. The sampling depth ranged from $9.3 \mathrm{~m}$ to $29.2 \mathrm{~m}$. The boreholes were drilled in a columnar manner. Samples were collected using a suction dredge with an internal diameter of $110 \mathrm{~mm}$. Twenty samples were selected for laboratory tests. All samples were preserved and delivered to the soil mechanics laboratory of Vilnius University.

Soil particle size distribution in all samples was determined using the hydrometer method in accordance with ISO 17892 - 4: 2016 Geotechnical investigation and testing - Laboratory testing of soil - Part 4: Determination of particle size distribution. For the assessment of physical properties of soil, we determined the following: soil initial bulk density $(\rho)$, particle density $\left(\rho_{s}\right)$, natural water content $(w)$, and Attenberg limits $\left(\mathrm{w}_{\mathrm{L}}, \mathrm{w}_{\mathrm{p}}\right)$. Also, we calculated the soil void ratio (e), water saturation $\left(\mathrm{S}_{\mathrm{r}}\right)$, liquidity index, consistency indicators $\left(\mathrm{I}_{\mathrm{L}}, \mathrm{I}_{\mathrm{C}}\right)$, and plasticity index $\left(\mathrm{I}_{\mathrm{P}}\right)$.

Undrained compressive strength tests were carried out using a triaxial compression apparatus with an automatic system of vertical pressure $\left(\sigma_{1}\right)$ transmission mechanism and vertical strain fixation. Diameter of the tested samples was $38 \mathrm{~mm}$, and height $80 \mathrm{~mm}$.

The undrained unconsolidated shear strength was determined in accordance with ISO 17892 -8: 2018 Geotechnical investigation and testing - Laboratory testing of soil - Part 8: Unconsolidated undrained triaxial test. Each sample was split into three subsamples that were tested under conditions of three different confining pressures $\left(\sigma_{3}\right)$, i.e. $50 \mathrm{kPa}, 100 \mathrm{kPa}$ and $150 \mathrm{kPa}$. The $\mathrm{c}_{\mathrm{u}}$ value was calculated by averaging $\left(\sigma_{1-} \sigma_{3}\right) / 2$ under three different confining pressures.

The axial deformation of the sample was carried out until failure (Fig. 1), or when the axial strain reached $15 \%$ (Fig. 2).
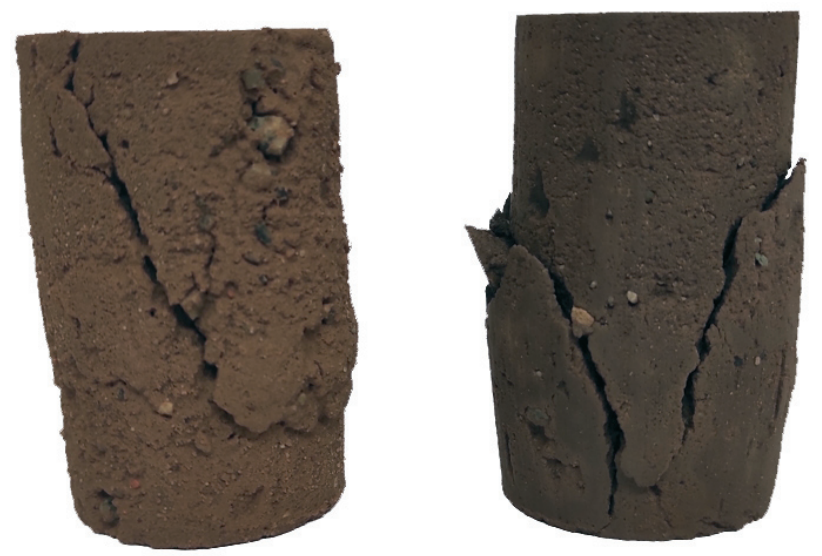

Fig. 1 Soil failure occurrence before vertical strain reaches $15 \%$
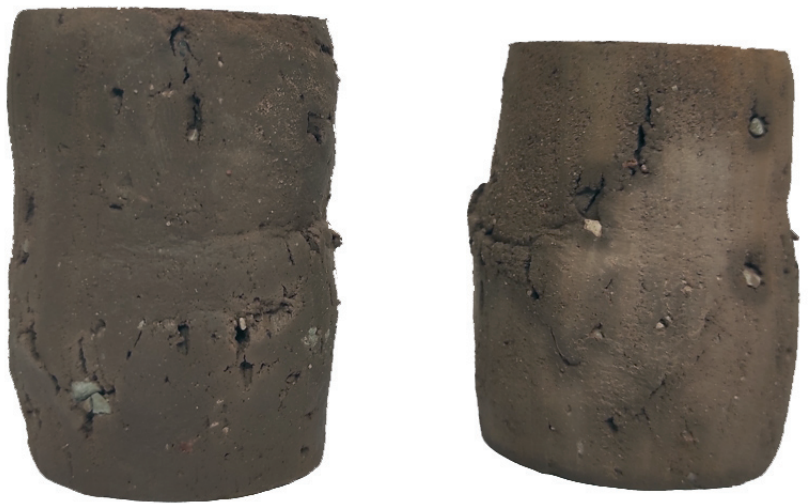

Fig. 2 Soil failure occurrence when vertical strain has reached $15 \%$ 
Under the impact of load, which was changed in the course of the test, the sample cross-sectional area $A$ became more extensive than the original sample cross-sectional area $A_{0}$. Thus, the area $A$ was calculated by the formula (1):

$$
A=\frac{A_{0}}{1-\varepsilon},
$$

where $A_{0}$ - initial sample cross-sectional area, $\mathrm{mm}^{2} ; \varepsilon$ - vertical strain ([-]).

Graphs of typical deviator stress dependences on the vertical strain are presented in Fig. 3.

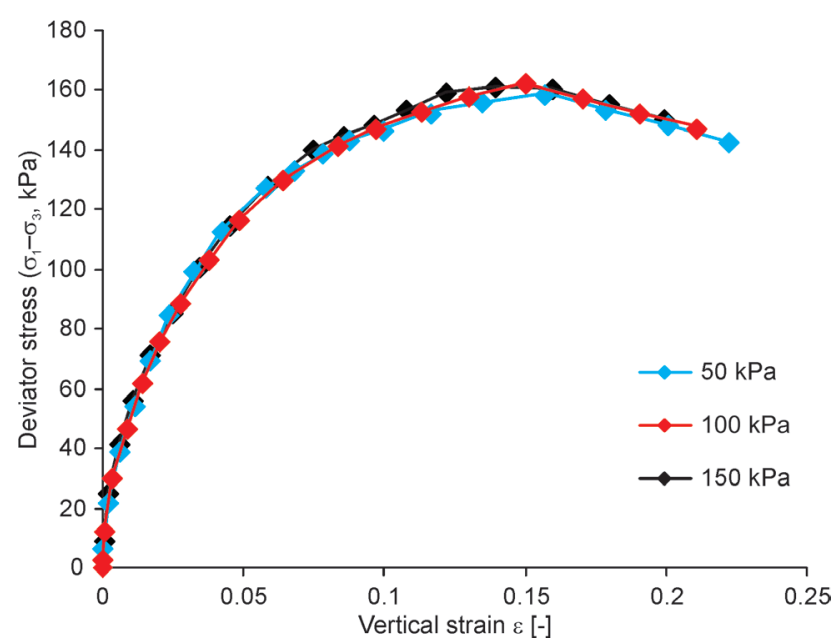

Fig. 3 Stress paths under three different confining pressures

\section{Test results and analysis}

The comprehensiveness and scope of the performed soil sample testing, assessment of the granulometric composition and physical condition of the tested soils as well as determination of the undrained soil shear strength made it possible to comprehensively assess both the homogeneity of the tested soil and the interdependence of the mentioned soil parameters.

Results of the undrained shear strength tests that were carried out using the triaxial compression method are presented in Table 1. The data obtained show quite a considerable variation in $c_{u}$ values. The minimum value of undrained shear strength was only $77.0 \mathrm{kPa}$, while the maximum one reached $183.0 \mathrm{kPa}$. The performed statistical evaluation of the change in these values and their heterogeneity delivered the following results: the average value was $124.6 \mathrm{kPa}$, standard deviation $-37.9 \mathrm{kPa}$, and the coefficient of variation $-30.5 \%$.

Although the scatter of cu values did not exceed the acceptable (30-40\%) coefficient of variation, its extent allowed for more detailed examination of the influence of various factors on the change in cu values.

Soil particle size distribution. The test results show that in the LST EN ISO 14688 - 2: 2018 classification, according to their granulometric composition, all till clays are attributed to a single type, i.e., sandy low plasticity clays ( $\mathrm{saClL}$ ). The performed analysis of the granulometric soil composition revealed some significant differences. Although the average percentage of clay fraction in the examined soil was approximately $20.0 \%$, its maximum (27.4\%) and minimum (13.0\%) values differed two times. The percentage of coarse fraction gravel in soil also showed a significant variation, i.e., from $1.2 \%$ to $7.6 \%$, although, in terms of its absolute value, the contribution of this fraction to the overall composition of the examined soil was weak.

The search for the interrelation between the particle size distribution and undrained shear strength allowed us to identify some close correlations. A very close correlation was observed between the clay fraction content (particle size $<0.002 \mathrm{~mm}$ ) and $c_{u}$ values (Fig. 4). The correlation coefficient $R$-value was equal to 0.912 .

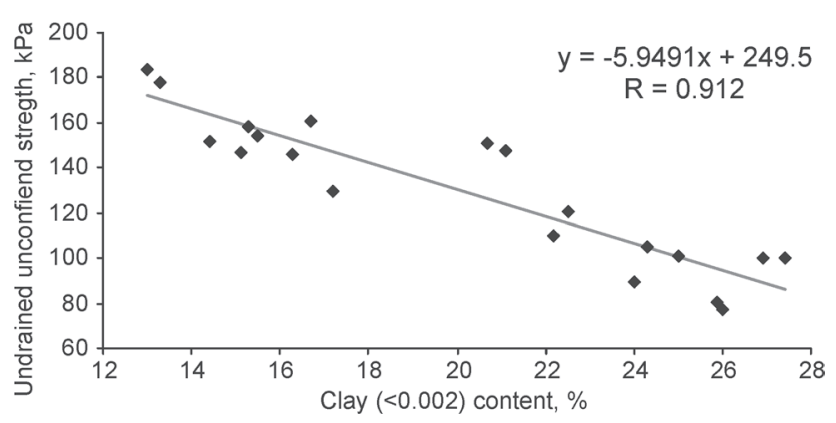

Fig. 4 Dependence of undrained shear strength on clay fraction content in soil

A very close correlation was found to exist between $c_{u}$ and the content of fine silt fraction (particle size $0.002-0.063 \mathrm{~mm}$ ), the correlation coefficient being equal to 0.909 (Fig. 5). This correlation was significantly improved (Fig. 6) by summing up clay and fine silt fractions and by correlating them with the values of the undrained soil shear strength. The correlation became closer, and $R$ was equal to 0.930 .

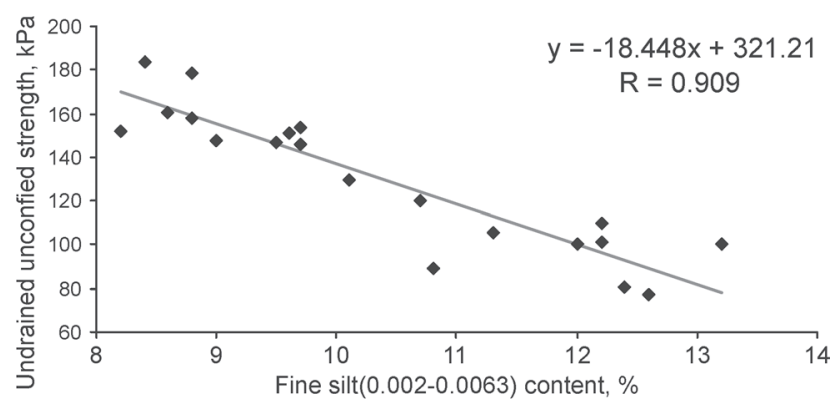

Fig. 5 Dependence of undrained shear strength on the content of fine silt particles

The data obtained indicate that there is an inverse correlation between the content of the above-men- 


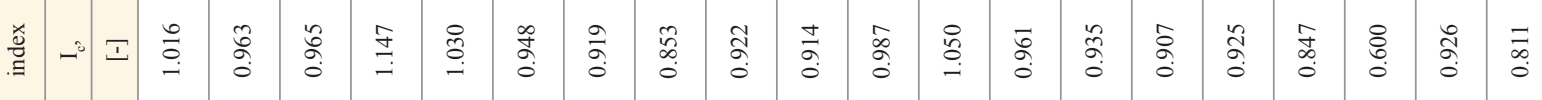

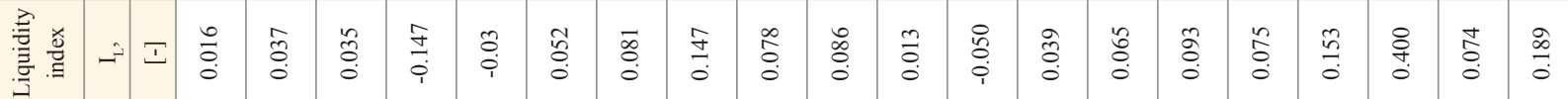

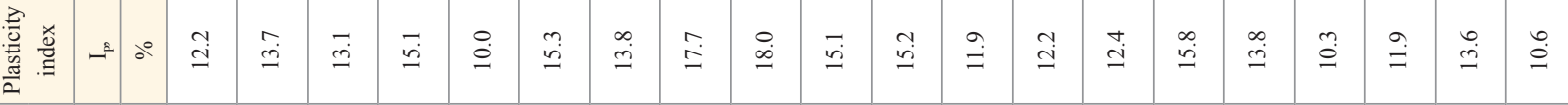

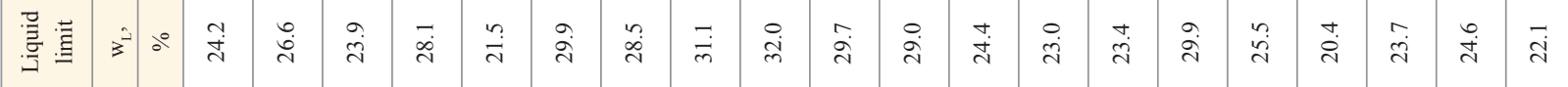

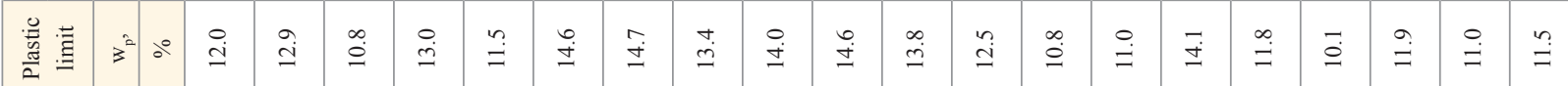

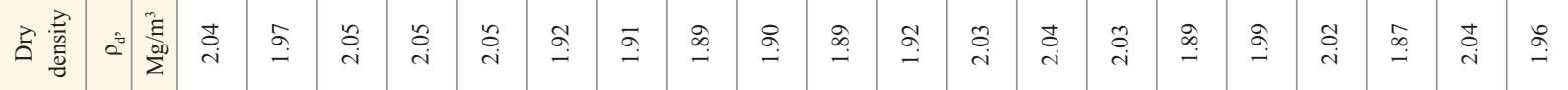

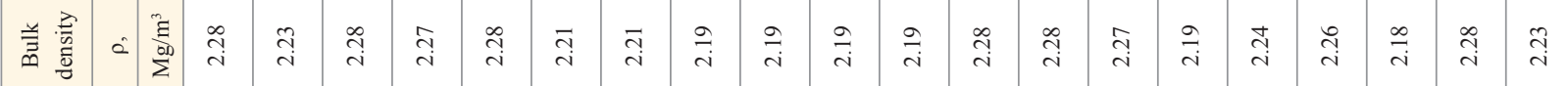

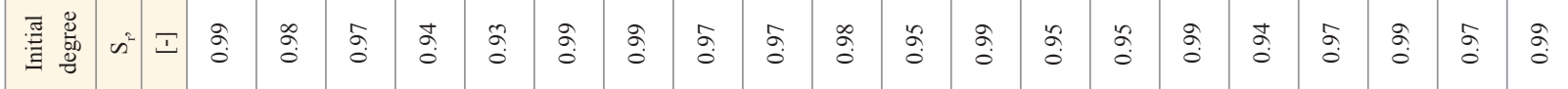

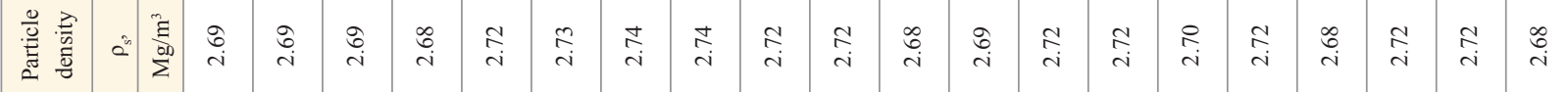

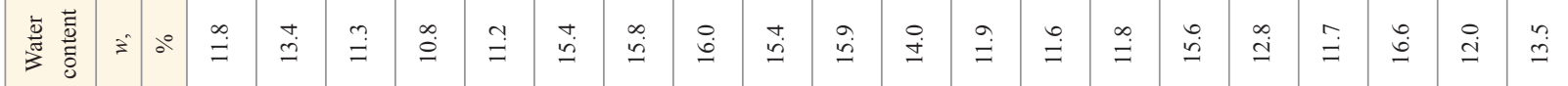

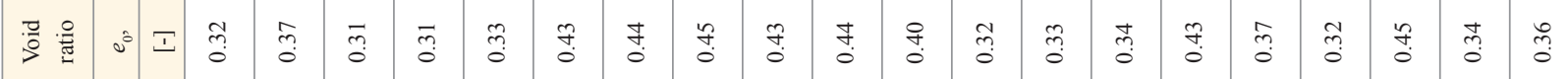

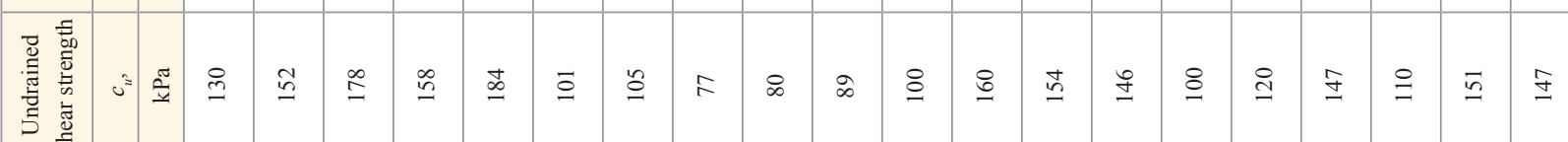

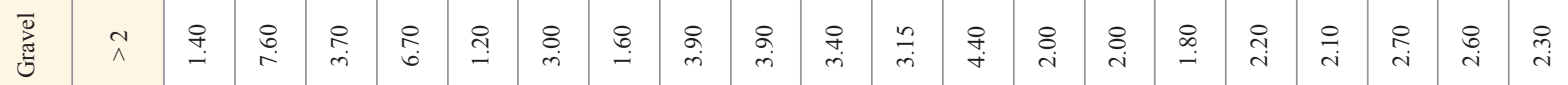

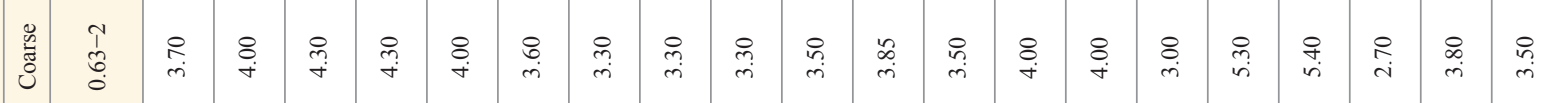

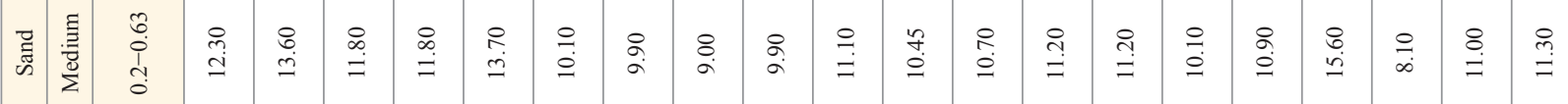

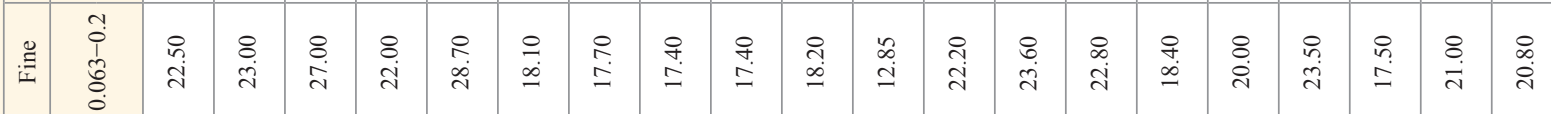

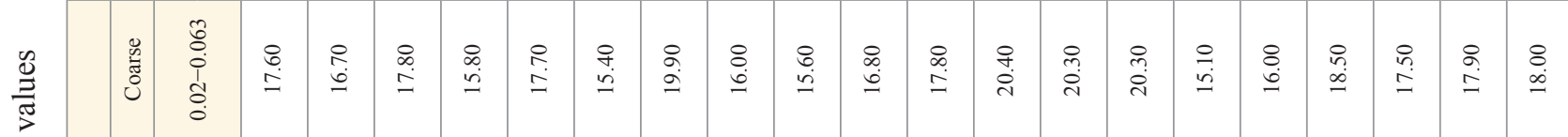

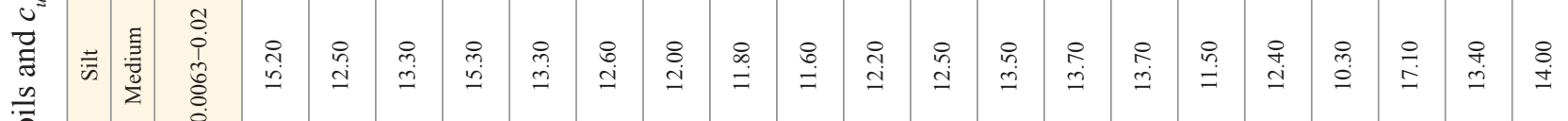

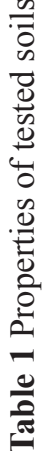

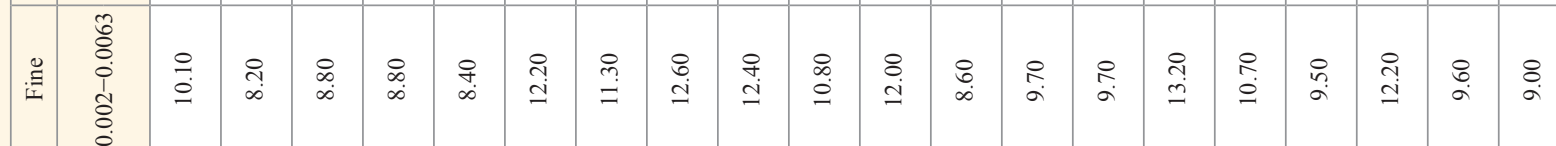

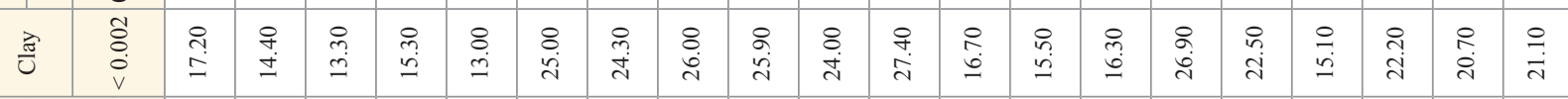

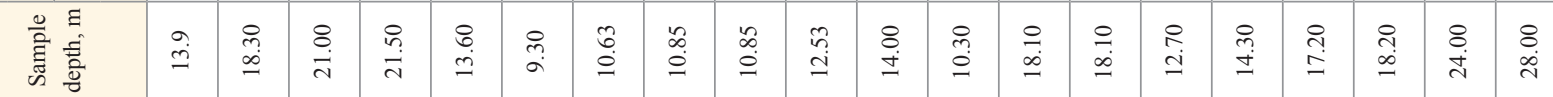

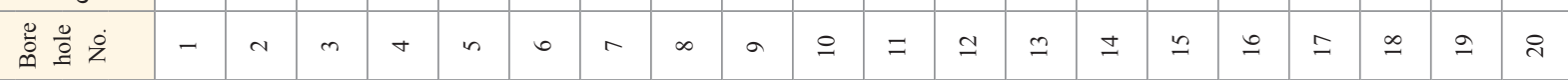




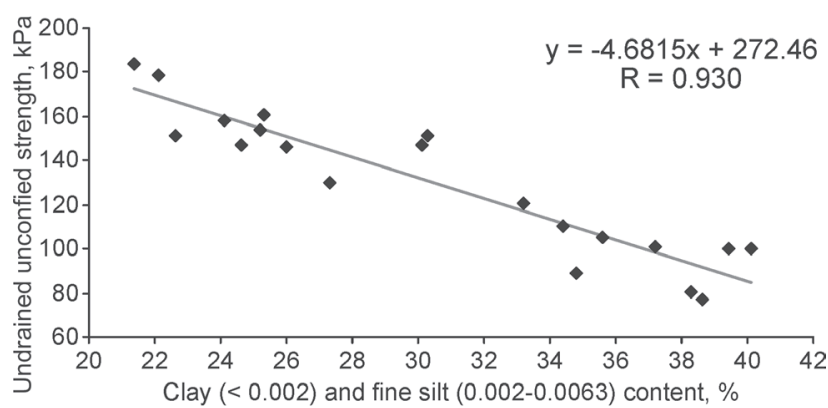

Fig. 6 Dependence of undrained shear strength on the content of clay and fine silt particles

tioned fractions in glacial till soil and its undrained shear strength.

\section{Physical condition}

Like all Lithuanian till soils, soil in the study area is characterised by a relatively similar density of solids ( $\rho)$, initial bulk density $(\rho)$, and dry soil density $\left(\rho_{d}\right)$. These parameters vary within a narrow range, i.e., from $2.0 \%$ to $5.0 \%$. The void ratio $(e)$ and natural water content $(w)$ values vary within a more significant range, which is $20.0 \%-24.0 \%$ on the average. The data are presented in Table 1 .

The performed correlation and regression analysis allowed us to estimate the closeness of correlations between the soil void ratio and undrained shear strength as well as between natural water content of soil and undrained shear strength (Figs 7 and 8). In both cases, the correlation was found to be close

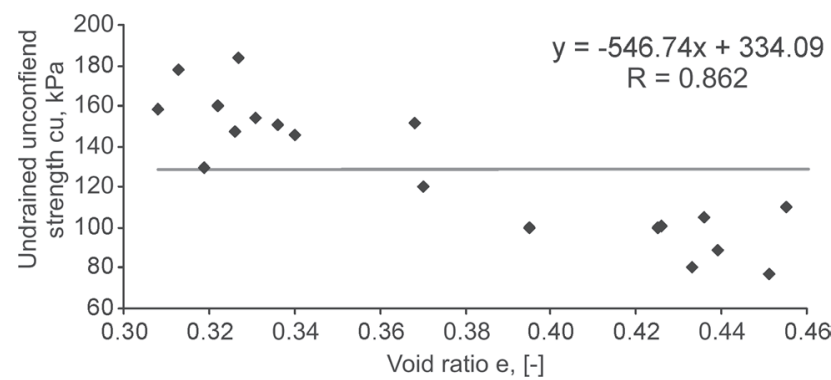

Fig. 7 Correlation between undrained shear strength and soil void ratio

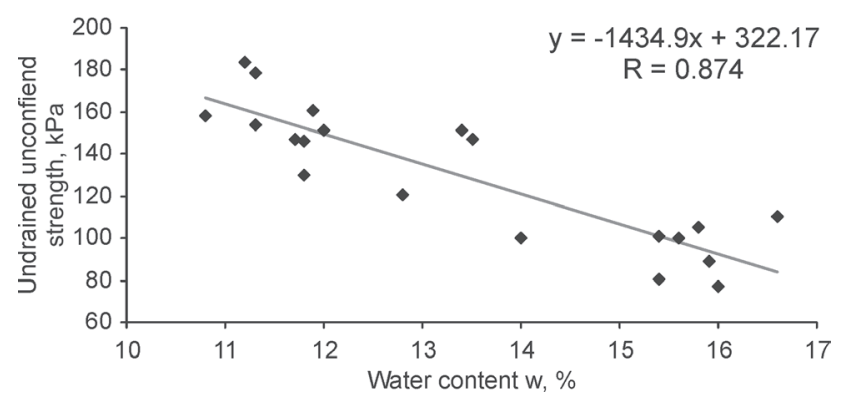

Fig. 8 Correlation between undrained shear strength and natural water content enough, $R$ being equal to 0.862 and 0.874 , respectively. However, this correlation was significantly lower than the previously mentioned correlation with the measured particle size distribution in soil.

Consistency parameters of glacial untilled soil are presented in Table 1. In the LST EN ISO $14688-$ 2: 2018 classification, all the tested soil samples are grouped with low plasticity soils. Values of the plasticity index $\left(I_{P}\right)$ range from $10 \%$ to $18 \%$. The average value is $13.6 \%$. Correlations between the undrained shear strength of soil and its plasticity index are close (Fig. 9). The correlation coefficient $R$ equals 0.739 .

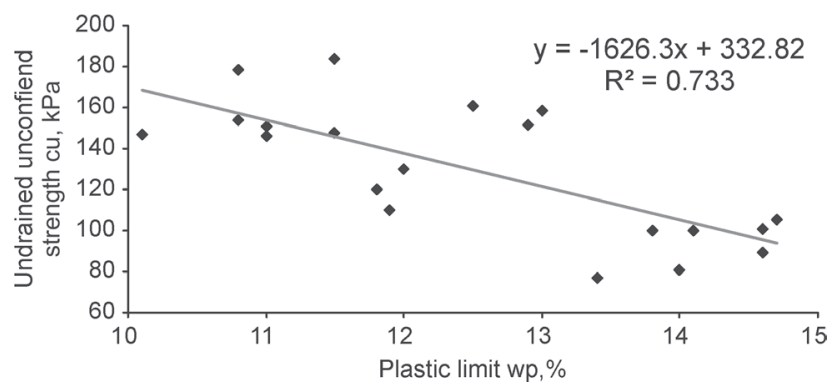

Fig. 9 Correlation between the plastic limit $\mathrm{w}_{\mathrm{p}}$ and $c_{u}$

Assessment of the tested soils' physical condition according to the consistency index $\left(I_{C}\right)$ showed that the majority of the examined soil samples were in a rigid consistency condition (15 samples) and only a few of them (4 samples) were in a very stiff consistency or solid consistency condition (1 sample). Consistency index values ranged from 0.6 to 1.147 , the average value equalling 0.931 . Our attempts to correlate $c_{u}$ values of the undrained soil shear strength with $I_{C}$ proved successful as the existence of a weak correlation between these parameters $(R=0.384)$ was revealed.

In summary, the correlation between plasticity of the tested soil and $c_{u}$ values partly reflects the content of clay and fine silt fraction, an approximate amount of fine particles $(<0.063 \mathrm{~mm})$ and clay percentage in soil (Dmitriev, Jarg 2008).

\section{DISCUSSION}

Of the above-discussed correlation dependencies, the correlation between the undrained shear strength of soil and soil particle size distribution was found to be the closest. The value of $c_{u}$ was observed to significantly decrease with an increase of clay and fine silt fraction content. The opposite phenomenon, i.e., an increase of $c_{u}$ values, was observed with the increase of sand fraction content.

A triangular diagram was plotted to represent all mineral fractions of the tested soils as a matrix (Fig. 10). In this diagram the marked area shows the distribution area of "optimal" fraction mixtures (Dun- 
dulis et al. 2004), i.e. soils that fall into this zone are characterized by the highest density, strength and the lowest compressibility. In the diagram, the test results are visualized as a kind of band, where values of the undrained soil shear strength increase as points of the granulometric soil composition approach the optimum mix zone. This tendency allows assessing the importance of the mineral fractions" "matrix".

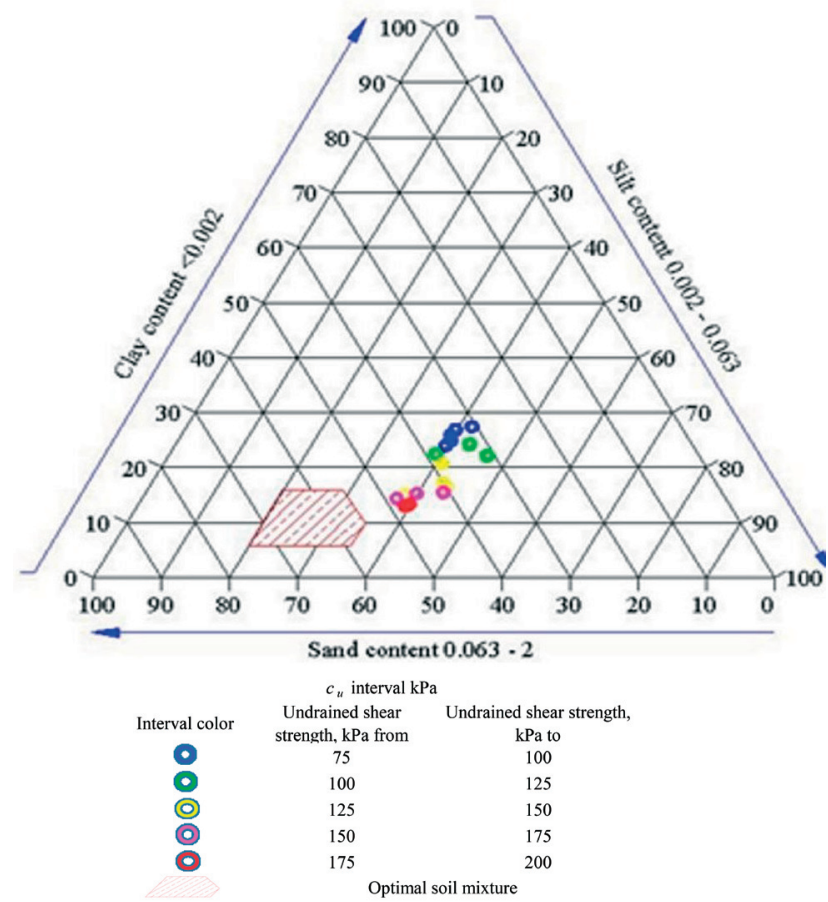

Fig. 10 Triangular diagram of the soil particle size distribution and its apparent correlation with undrained shear strength

The revealed close correlation between $c_{u}$ and void ratio $e$ allows evaluating the role of the soil mineral content in filling soil pore spaces. Based on the research findings reported by Thevanayagam (1998) and Benahmed Nguyen et al. (2015), we assessed the impact of the content of different fractions on pore spaces in the soil mineral matrix. As a result of theoretical removal of one or another fraction from natural soil structure, its porosity changes. It can be calculated according to the following formula:

$$
e_{i}=\frac{e_{0}+f_{s}}{1-f_{s}}
$$

To increase the accuracy of these calculations, the authors modified the formula by including dry soil density into it:

$$
e_{i}=\frac{\rho_{s}}{\rho_{d}-\frac{f_{s} \times \rho_{d}}{100}}-1
$$

where $\boldsymbol{e}_{\boldsymbol{i}}-$ void ratio after removal of fractions; $\boldsymbol{\rho}_{\boldsymbol{s}}-$ particle density, $\mathrm{Mg} / \mathrm{m}^{3}, \boldsymbol{f}_{\mathrm{s}}$ - the amount of removed fraction, $\%, \boldsymbol{\rho}_{d}-$ dry density, $\mathrm{Mg} / \mathrm{m}^{3}$.
The calculations presented in Table 2 clearly show that as a result of the theoretical removal of the clay fraction (particles $<0.002 \mathrm{~mm}$ ) from high shear strength soils (from $110.0 \mathrm{kPa}$ to $183.0 \mathrm{kPa}$ ), the residual void ratio changed and varied from 0.51 to 0.77 . The residual void ratio values indicate that sand and silt fractions form a high- and medium-density sandy silt framework for a stable matrix. When $c_{u}$ values are in the range of $77.0 \mathrm{kPa}-105.0 \mathrm{kPa}$, the residual porosity $e_{i}$ increases to $0.89-0.96$. In this case, the framework of the powdery sand and silt mixture is formed. Such a framework could be stable in itself, but under impact load, it would deform easier.

Table 2 Changes in soil void ratio after removal of clay fractions and those of clay and fine silt

\begin{tabular}{|c|c|c|c|}
\hline \multirow{2}{*}{$\begin{array}{c}\text { Undrained } \\
\text { Shear strength } \\
\text { cu, kPa }\end{array}$} & \multicolumn{3}{|c|}{ Void ratio e } \\
\cline { 2 - 4 } & Natural & $\begin{array}{c}\text { Removed } \\
\text { clay fraction }\end{array}$ & $\begin{array}{c}\text { Removed clay and } \\
\text { fine silt fractions }\end{array}$ \\
\cline { 2 - 4 } & $e_{0}$ & $e_{1}$ & $e_{2}$ \\
\hline 77 & 0.45 & {$[-]$} & {$[-]$} \\
\hline 80 & 0.43 & 0.95 & 1.36 \\
\hline 89 & 0.44 & 0.89 & 1.32 \\
\hline 100 & 0.40 & 0.93 & 1.21 \\
\hline 100 & 0.43 & 0.96 & 1.31 \\
\hline 101 & 0.43 & 0.90 & 1.39 \\
\hline 105 & 0.44 & 0.90 & 1.28 \\
\hline 110 & 0.45 & 0.73 & 1.24 \\
\hline 120 & 0.37 & 0.77 & 1.05 \\
\hline 130 & 0.32 & 0.59 & 1.05 \\
\hline 146 & 0.34 & 0.60 & 0.81 \\
\hline 147 & 0.32 & 0.55 & 0.81 \\
\hline 147 & 0.36 & 0.72 & 0.75 \\
\hline 151 & 0.37 & 0.60 & 0.77 \\
\hline 151 & 0.34 & 0.69 & 0.92 \\
\hline 153 & 0.33 & 0.57 & 0.78 \\
\hline 158 & 0.31 & 0.55 & 0.72 \\
\hline 160 & 0.32 & 0.58 & 0.77 \\
\hline 178 & 0.31 & 0.51 & 0.68 \\
\hline 183 & 0.33 & 0.53 & 0.69 \\
\hline & & & \\
\hline
\end{tabular}

After the theoretical removal of clay (particles $<$ $0.002 \mathrm{~mm}$ ) and fine silt (from $0.002 \mathrm{~mm}$ to $0.0063 \mathrm{~mm}$ ) particles within the previously mentioned range of $c_{u}$ values, an average-density powdery sand and silt framework was obtained in the first case, while in the second case $\left(e_{i}>1\right)$, this mixture did not form a framework.

The data obtained reaffirm the importance of the soil particle size distribution and soil porosity for the shear strength of undrained soil.

\section{CONCLUSIONS}

1. According to the particle size distribution and physical properties, the tested soil samples are attrib- 
utable to sandy low plasticity clays of stiff and very stiff consistency.

2. As indicated by the obtained coefficient of variation $(30.5 \%)$ of the undrained shear strength values, the tested soils are quite homogeneous in respect of undrained shear strength.

3. The contents of clay and fine silt fractions (in percentage terms) have a decisive impact on the shear strength of undrained soils.

4. The void ratio, as well as natural water content and, accordingly, consistency parameters, is an additional factor influencing undrained soil shear strength.

5. A sufficiently clear sequence was observed: values of the undrained soil shear strength decrease as the particle size distribution moves away from the optimal mixture of till soils.

6. The dual impact of clay fractions and fine silt on the durability of soil mineral framework was ascertained.

\section{ACKNOWLEDGMENTS}

The authors are grateful to two anonymous reviewers for providing useful comments on the paper.

\section{REFERENCES}

Benahmed, N., Nguyen, T.K., Hicher, P.Y., Nicolas, M. 2015. An experimental investigation into the effects of low plastic fines content on the behaviour of sand/silt mixtures. European Journal of environmental and civil engineering 19 (1), 109-128. https://doi.org/10.1080/19648189.2014.939304

Bond, A., Harris, A. 2008. Decoding Eurocode 7. CRC Press. ISBN 9780415409483

Broms, B.B., Bennermark, H. 1967. Stability of clay at vertical openings. Journal of the Soil Mechanics and Foundations Division 93 (1).

Burland, J.B. 1990. On the compressibility and shear strength of natural clays. Géotechnique 40 (3), 329378. https://doi.org/10.1680/geot.1990.40.3.329

Carrier, W.D., Beckman, J.F. 1984. Correlations between index tests and the properties of remoulded clays. Geotechnique 34 (2), 211-228. https://doi.org/10.1680/geot.1984.34.2.211

Dmitriev, V.V., Jarg, L.A. 2008. Metody i kačestvo laboratornogo izučenija gruntov: učebnoe posobie. M.: KDU (In Russian).
Dundulis, K., Gadeikis, S., Ignatavičius, V. 2004. Evolution of engineering geological conditions. Evolution of Earth in Lithuania. Crust and its resources in Lithuania, 318-330. Vilnius.

Frank, R. 2004. Designers' guide to EN 1997-1 Eurocode 7: Geotechnical design - General rules. Thomas Telford. ISBN: 9780727731548

ISO 17892 - 4: 2016. Geotechnical investigation and testing - Laboratory testing of soil-Part 4: Determination of particle size distribution.

ISO 17892 - 8: 2018. Geotechnical investigation and testing - Laboratory testing of soil - Part 8: Unconsolidated undrained triaxial test.

LST EN ISO 14688 - 2: 2018. Geotechnical Investigation and Testing - Identification and Classification of SoilPart 2: Principles for a Classification.

Ortigão, J.A.R. 1995. Soil mechanics in the light of critical state theories. Vol. 2. CRC Press.

Powrie, W. 2004. Soil mechanics. Concepts and applications. 2nd ed. Spon Press. London. ISBN 9780415311564

Sharma, B., Bora, P.K. 2003. Plastic limit, liquid limit and undrained shear strength of soil reappraisal. Journal of Geotechnical and Geoenvironmental engineering 129 (8), 774-777. https://doi.org/10.1061/(ASCE)1090-0241(2003)129:8(774)

Sheahan, T.C., Ladd, C.C., Germaine, J.T. 1996. Ratedependent undrained shear behavior of saturated clay. Journal of Geotechnical Engineering 122 (2), 99-108. https://doi.org/10.1061/(ASCE)0733-9410(1996)122:2(99)

Skempton, A.W. 1948. The $\varphi=0$ analysis of stability and its theoretical basis. In: Proceedings of the 2 nd International Conference on Soil Mechanics and Foundation Engineering 1, 72.

Sližyte, D., Medzvieckas, J. 2013. Evaluation of gravity retaining walls from jet grouting piles installed in sands. Procedia Engineering 57, 1070-1077. https://doi.org/10.1016/j.proeng.2013.04.135

Thevanayagam, S. 1998. Effect of fines and confining stress on undrained shear strength of silty sands. Journal of Geotechnical and Geoenvironmental Engineering 124 (6), 479-491. https://doi.org/10.1061/(ASCE)1090-0241(1998)124:6(479)

Uhov, S.B., Semenov, V.V., Znamenskij, V.V., Ter-Martirosjan, Z.F., Černyšev, S.N. 2004. Soil mechanics, soil basics and foundations, 256-258. Moskva: Vysšaja škola (In Russian).

Wroth, C.P. 1987. The behaviour of normally consolidated clay as observed in undrained direct shear tests. Geotechnique 37 (1), 37-43. https://doi.org/10.1680/geot.1987.37.1.37 